\title{
Space for virtue in the economics of Kenneth J. Arrow, Amartya Sen and Elinor Ostrom*
}

* I would like to thank Patrick Hough for his insights and help in developing this argument.

Author details:

Dr Dominic Burbidge

University of Oxford, Department of Politics \& International Relations

dominic.burbidge@,politics.ox.ac.uk

Word count: 9,685

\begin{abstract}
:
Virtue ethics interprets human action as pursuing good ends through practices that develop qualities internal to those final goals. The philosophical approach has been identified as critical of economics, leading in turn to the innovative response that by viewing the market as mutually beneficial exchange, economic practice is in fact defendable on virtue ethics grounds. This defends economics using arguments drawn from virtue ethics, but there is a need also to explore space for virtue ethics within economic theory. Examining key contributions of Kenneth J. Arrow, Amartya Sen and Elinor Ostrom, the article notes that virtue ethics' appreciation of persons' communicability of ends is increasingly being relied upon within economics, though sometimes under different names. Its strength to interdisciplinary work between economics and philosophy lies in presenting a methodology able to capture how human beings are capable of, though not fixated on, cooperation.
\end{abstract}

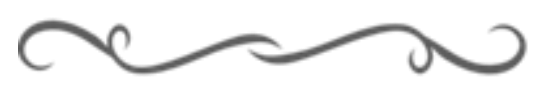

Virtue ethics holds that pursuit of the good involves practising habits that dispose oneself readily to one's ultimate goals. The ends of activities are what people are after, but they need to practise obtaining them to deepen and solidify habits of conduct. Though increasingly popular, this school of philosophy has been perceived as anathema to economic methodology because it challenges assumptions of self-interested human motivation. Economic thought is, generally speaking, a school associated with one of the main philosophical contestants to virtue ethics, utilitarianism (Sandel, 2012). Can any common ground be found between virtue ethics and economics? If so, what would a 
mutually compatible methodology look like? In response to the supposed disagreement, Bruni and Sugden (2013) write a defence of economics using arguments drawn from virtue ethics. They outline how the market can be discussed as a good in itself because it achieves 'mutual benefits gained by individuals as parties to voluntary transactions' (p. 143). Particular virtues can be said to support the good practice of market transactions: universality, enterprise and alertness, respect for the tastes of one's trading partners, trust and trustworthiness, acceptance of competition, self-help, non-rivalry, and stoicism about reward. Bruni and Sugden's excellent riposte not only defends economics from a virtue ethics attack but also indicates interesting areas of synergy between the two positions.

Bruni and Sugden found space for virtue theory by identifying those virtues that both support the development of the economy as a whole and link to individual-level economic activity. Notwithstanding their efforts, any meeting of methodologies between disciplines also demands an effort on the part of economic theory to identify if and how virtue theory can be accommodated there. In this vein, the article traces economic theory that has developed significant areas of methodological crossover with the emerging virtue ethics tradition, inviting further research into what it means for connecting individual activity to the economy as a whole. The argument does not take these compatible areas of economics research to have had this compatibility in mind as they were developing, nor is their use and interpretation now to be considered an exclusive domain of virtue ethics. Rather, the exercise is one of refining common areas of inquiry to encourage critical exchange between virtue ethics and economics. Bruni and Sugden wrote a defence of economics using arguments drawn from virtue ethics; the present article submits a defence of virtue ethics drawn from economics. Seeing these areas of crossover from both sides helps enrich methodological attention to the two disciplines' assumptions, encouraging interdisciplinary debate.

To achieve this goal, the article traces key developments in micro and behavioural economic theory to point out how the benefits of methodological synergy with virtue ethics are already on offer. This is not due to a conscious effort to merge traditions but because of significant research into the question of why humans cooperate when it is not in their immediate self-interest. Three well-known economists stand out as tackling this question head-on, with all pointing in varying degrees to the role virtues play in human motivation and interpersonal coordination: Kenneth J. Arrow, Amartya Sen and Elinor Ostrom. Many other economists have also considered why humans cooperate, so the account here does not claim to be exhaustive. Rather, the thinkers have been chosen because they present an interconnected strain within micro and behavioural theory that has relied, both directly and indirectly, on conceptions of social virtue unusual for standard economic theory. Further, the authors have each found benefit in aspects of each other's work, helping generate dialogue. Evaluating and cross-examining the thoughts of Arrow, Sen and Ostrom, the article finds that the communicability of ends contained in virtue ethics — though often found challenging — is implicitly providing a new methodological strategy for answering economic questions of trust, cooperation and the formation of social capital. 


\section{Kenneth J. Arrow}

In a 1972 article, Arrow makes explicit reference to the way in which non-market ties of trust support economic transactions:

It is obvious on the most superficial observation that the allocation of goods and services is not accomplished entirely by exchange, as standard economic models would hold. Clearly this is true for such impalpable goods as respect, love, or status, but even when we confine ourselves to goods whose allocation the economist believes himself capable of analyzing... (pp. 344-5)

The source for Arrow's concession is his reading of Titmuss' The Gift Relationship (1970), which explored how blood donations in the United Kingdom are made on a voluntary basis whilst in the United States they are often made on a corporate basis. Framing the puzzle of voluntary blood donation, Titmuss asks: "Why should men not contract out of the "social" and act to their own immediate advantage? Why give to strangers?' (p. 15). Seeking to interpret this, Arrow (1972, pp. 345-6) links the concept of virtue to economic life:

It can be argued that the presence of what are in a slightly old-fashioned terminology called virtues in fact plays a significant role in the operation of the economic system. Titmuss calls attention to the great value of truthfulness on the part of blood donors; the most serious risk in blood transfusion is the possible transmission of serum hepatitis from donor to recipient. Since no adequate test has yet been devised for the presence of hepatitis in the blood, its detection depends essentially on the willingness of the donor to state correctly whether or not he is suffering from that disease. This is a prototype of many other similar situations in economic life. Many of us consider it possible that the process of exchange requires or at least is greatly facilitated by the presence of several of these virtues (not only truth, but also trust, loyalty, and justice in future dealings).

The above is worth quoting in full because of the reference made by Arrow to honesty in selfidentifying serum hepatitis symptoms, which represents a similar challenge to cooperative dilemmas in that a functioning solution relies on some form of standardised disposition to act in a way that keeps others' interests in mind.

A further link by Arrow to the importance of trust and virtue is made when referencing Banfield's The Moral Basis of a Backward Society (1958). Arrow (1972, pp. 356-7) concludes:

it strikes me that the essential point is the great importance of such a virtue as truthfulness in widely prevalent circumstances of economic life. I have remarked on the responsibility for truthfulness in economic life, but the issue goes even further. Virtually every commercial transaction has within itself an element of trust, certainly any transaction conducted over a period of time. It can be plausibly argued that much of the economic backwardness in the world can be explained by the lack of mutual confidence; see Banfield's remarkable study of a small community in southern Italy.

Here Arrow draws connections between virtue, trust and the social capital of a community (social capital defined generally as the norms and networks that enable collective action). Interestingly, Banfield's study, which Arrow cites, is a little-acknowledged forerunner to Putnam's 1993 work on 
Italy, which in turn achieved so much in sparking contemporary interest in social capital and trust. Banfield summarises his work as 'about a single village in southern Italy, the extreme poverty and backwardness of which is to be explained largely (but not entirely) by the inability of the villagers to act together for their common good' (1958, p. 10). Such a line could be inserted into Putnam's work seamlessly (see discussion in Knack, 2002, pp. 773-4). For Banfield, the village in question lacks 'a significant element of public spiritness or even of "enlightened" self interest' (1958, p. 12) and, à la Putnam, this is explained as in part attributable to a lack of associational behaviour, for example consternation in the forming of football teams (pp. 173-4).

Having thus, in a loose and embryonic way, brought together the three elements of virtue, trust and social capital, Arrow is nonetheless reluctant to draw wider conclusions along such lines. For economic modelling he cautions that ' $[\mathrm{w}]$ holesale usage of ethical standards is apt to have undesirable consequences' and, as a tool of analysis, should only be applied to scenarios where the price system has broken down (1972, p. 355). ${ }^{1}$ F urther, he goes so far as to accuse Titmuss' argument as having 'a rather elitist flavor' (p. 360) because it presumes volunteer enthusiasm will wither away once money is brought in:

[T] he high value of altruism or whatever other virtue is threatened by the growth of commercialization will still hold even after the price system has spread somewhat. What Titmuss would be afraid of, I take it, is that other, weaker souls would somehow succumb. [...] Now, the argument that we should therefore not permit a commercial system amounts to saying both that I am more foresighted than my contemporaries and that my virtue is less assailable. (pp. 360-1)

Two closely connected things are going on here. The first is hesitation in moving from studying the indirect causes of aggregate change to direct questions of human motivation and deliberation. The extent of social science preference for exploring indirectness and aggregate change through simplifying individual-level motivation is well identified by Finnis, who notes the importance of 'sideeffects' for Adam Smith's understanding of social development (1990, p. 195),2 a preference in agreement with David Hume's method and reaching in its sentiments at least as far back as Thomas Hobbes and those assumptions that first set the social sciences in motion. Such a persuasion is evidenced by Arrow's protection of the role of the economist, arguing for instance how, 'like many economists, I do not want to rely too heavily on substituting ethics for self-interest' (1972, p. 354), a commitment to clear separation of disciplines.

The second thing going on is an implicit and false association of virtue with will power. Without being able to address here the history of the concept of virtue, it is nevertheless crucial to distinguish between Aristotelian and Stoic conceptions. Whilst Aristotelian philosophers emphasise certain indeterminacy in both the accruing and specification of the virtues, Stoics explore the determining capacity of the will to overcome vicious or emotional attachments and so ensure a life of virtue. ${ }^{3}$ Arrow's understanding is more Stoic than Aristotelian and, from this position, evaluation of virtue all too easily slides into evaluation of will power. The formulation then naturally troubles the economist, for will power should be dictated by market incentives, and not the other way around. 
Thus, when the indirect methodology of economics meets with assessment of virtue as a capacity for direct will power, introducing the latter into analysis is rejected as elitist and potentially unscientific.

For the same reason, in a 2000 publication Arrow urges 'abandonment of the metaphor of capital and the term, "social capital”' (p. 4). Describing social relations in this way, he observes, fails to fit the definition of capital, which is characterised by: '(a) extension over time; (b) deliberate sacrifice in the present for future benefit; and (c) alienability.' The concept fails most especially on the second criterion of these because the social connections through which social capital is accumulated tend to be pursued for their own sake, rather than for their future economic value: 'The essence of social networks is that they are built up for reasons other than their economic value to the participants' (p. 4). Arrow's criticism has been widely discussed, with Robison et al (2002, p. 8) counter-arguing that social capital understood as accumulated 'sympathy' does indeed bear opportunity costs when pursued, for example in giving things and time to friends to help foster the human and emotional bonds between. ${ }^{4}$ However, this counter-argument fails because one does not sacrifice social capital itselffor future benefit, but rather other forms of capital. Social capital cannot be sacrificed in the present for future gain, for it increases through use (Gambetta, 1988, p. 234; Ostrom, 2000, pp. 179-80). The question, therefore, is instead why an economic definition of capital requires that items suffer diminishment when used, a question Arrow avoids.

Underlying Arrow's stance is discomfort at unnecessarily mixing the study of direct and indirect human agency. Theories of trust, virtue and social capital seem dangerously counterpois ed to the normal study of economics, for they interest themselves in intentional behaviour and not just indirect effects. Viewing the accumulation of capital as necessarily 'deliberate sacrifice in the present for future benefit' is again a Stoic stance, emphasising how the person betters themselves through applying the will and foregoing present enjoyment. Economic productivity is a duty; its enjoyment is to be postponed. To this position, the burgeoning social capital and trust literature is a difficult bedfellow, for it holds that the enjoyment of direct goods such as socialising can also have indirect benefits. One example of the social capital position that illustrates this difference is the house meetings organised by Valley Interfaith—highlighted by Putnam and Feldstein (2003)as creating social capital. The authors explain:

These home visits, the face-to-face conversations between a teacher and a child's parent or parents, gradually built up a group of parents who believed enough in the possibility of improving the schools (and believed enough in the goodwill of the teachers) to meet together to take the next step in organizing and planning. (p. 12)

Compared to standard economic texts, this is emotional language and littered with references to direct and present intention. Indeed, described as a form of capital, such 'relational organizing' (Putnam \& Feldstein, 2003, p. 13) necessarily conflicts with the definitional requirement that capital must involve deliberate sacrifice of the present. Further eroding the supposed monopoly of capital over notions of stoic sacrifice, Bruni and Sugden describe 'stoicism about reward' as an economic virtue (2013, pp. 159-60), which suggests they think it less a necessary component to capital as a useful disposition that 
anyone engaged in economic activity should naturally accrue. Indeed, why should 'deliberate sacrifice in the present for future benefit' be a definitional requirement of capital?

It is perhaps because of Arrow's fears of the unwieldy and intervening nature of discourse over virtue that his 1974 work addressing similar themes, The Limits of Organization, returns to the debate by placing trust and the virtues under the concept of market 'externalities':

Trust is an important lubricant of a social system. It is extremely efficient; it saves a lot of trouble to have a fair degree of reliance on other people's word. Unfortunately this is not a commodity which can be bought very easily. If you have to buy it, you already have some doubts about what you've bought. Trust and similar values, loyalty or truth-telling, are examples of what the economist would call "externalities." They are goods, they are commodities; they have real, practical, economic value; they increase the efficiency of the system, enable you to produce more goods or more of whatever values you hold in high esteem. But they are not commodities for which trade on the open market is technically possible or even meaningful. (p. 23; see also Arrow, 1970, p. 20)

Demarcating such a territory for trust and virtue is well within the rights of an economist's vocation of interpreting the indirect consequences of exchange activity. Generally, externalities are defined as 'unpaid side effects of one producer's output or inputs on other producers', with a positive example being 'a dam constructed by a hydroelectric power plant [that] eliminates flooding of farmers' crop fields' (Bohm, 2008, p. 189). This reflection on how something else can be produced as a by-product of a specific pursuit is a conceptual framework that does indeed have crossovers with a theory of virtue, even if it fails to show quite the enthusiasm that virtue ethicists would prefer. The way it works is that in pursuing our self-interests, we form practices of truth-telling and trust that in turn act as useful social by-products. As compared with a virtue ethics approach, the analy tical space is helpfully similar though a clear difference remains. Whereas Arrow sees bilateral pursuits as leading to social virtues (essentially one-way causal), virtue ethicists see social virtues as both a product of bilateral pursuits and a supporter of them, because virtues can also be intentionally pursued by individuals (allowing two-way causal directions). The necessary adjustment economists interested in virtue theory would have to make would be for side effects of production to be integrated into an account of personal development. Without this, treating social virtues as norms likely to erode if exposed to market forces does indeed remain elitist and frustratingly disconnected from individual capacities for selfdevelopment.

In a comparable framing to Arrow's discussion of social virtues as externalities, MacIntyre distinguishes between internal goods and external goods and argues that the virtues develop the internal through pursuit of particular, concrete, external goods. An example is the practice of carpentry which involves crafting furniture (the external good) and in the process develops skills and virtues in the carpenter (internal goods). If one takes external goods to be economic goods, and internal goods to be certain positive externalities conducive to market norms of mutually beneficial exchange, there is some crossover between the two sets of categorisation. For example, MacIntyre (1985, pp. 190-1) writes: 
External goods are $[\ldots]$ characteristically objects of competition in which there must be losers as well as winners. Internal goods are indeed the outcome of competition to excel but it is characteristic of them that their achievement is a good for the whole community who participate in the practice.

As a way of structuring analy sis, therefore, there looks in the first instance to be promising connection between this view of the virtues and Arrow's use of externalities.

Disagreement lies in how Aristotelian virtue theorists, such as MacIntyre, frame the virtues as necessarily good. Here the reply of economic theory will invariably be that an externality can only be judged by its consequences, not by its nature. Arrow frames his 1974 analysis as in the spirit of an economist', noting how '[a $]$ n economist by training thinks of himself as the guardian of rationality, the ascriber of rationality to others, and the prescriber of rationality to the social world' (p. 16) and therefore someone who takes no view on whether something is morally good or bad. Arrow furthers this by specifying:

A truly rational discussion of collective action in general or in specific contexts is necessarily complex, and what is even worse, it is necessarily incomplete and unresolved. Rationality, after all, has to do with means and ends and their relation. It does not specify what the ends are. (p. 17)

This move suddenly renders Arrow's discussion antithetical to Aristotelian virtue theorists who, grounded in a concept of 'man-as-he-could-be-if-he-realized-his-essential-nature' (MacIntyre, 1985 , p. $52)$, view pursuit of human goods ( tele $)^{5}$ as stable reference points for interpreting positive habits of practice. Virtue ethics' concept of the good is purposefully vague, but unifying nonetheless because ends are seen as mutually intelligible. Annas, a virtue ethicist, describes the accumulation and practice of virtue as sharing the intellectual structure of a skill where we find not only the need to learn but the drive to aspire, and hence the need to "give an account", the need for articulate conveying of reasons why what is done is done' (2011, p. 20). This presumes a minimal communicability of the underlying virtues, whereby diverse experiences remain relevant to others one meets and the virtues become part of the reason why one is acting. Indeed, a key difference between a Humean and an Aristotelian understanding of virtue is precisely the latter's commitment to the communicability of character and ends between persons (see Hume, 1978, p. 471). The Aristotelian approach avoids intersubjective communication by means of interest-based signalling and instead admits broader social purposes as possible intentions for acting.

Arrow makes key strides towards Aristotelian considerations by focusing on how ‘interpersonal relationships are needed as part of our collective organization’ (1974, p. 18) and, when discussing the 'invisible institutions' of morals, by noting that: '[c] ertainly one way of looking at ethics and morality, a way that is compatible with this attempt at rational analysis, is that these principles are agreements, conscious or, in many cases, unconscious, to supply mutual benefits' (p. 26). But the radical value of such 'agreements' is not expanded upon and there is reluctance to explore where they are located. For example, after distinguishing between personal and impersonal authority 
within institutions, Arrow prefers analysis of the impersonal, which consists of codes of conduct and the law, returning the student to the nature of formal organisations rather than their limits (pp.63, 78). Having opened the question of the shortcomings of institutional analysis, therefore, Arrow fails to follow where it leads. As much is also the case with his situating of the social virtues as externalities, which comes only after a 1969 piece that posits how externalities can be internalised into economic models by reinterpreting the commodity space (see also Arrow, 1970, p. 14). If that is the general approach, it appears more a strategy of moving the problem than endorsing any particular explanation. Nevertheless, Arrow's discussions spark debate on the interconnectivity between virtue and trust within economics by exposing the limits of institutional explanations of economic activity and offering space for how social virtues play an important role.

\section{Amartya Sen}

Much as with Arrow, Sen sees how capitalism is undergird by a normative structure:

While capitalism is often seen as an arrangement that works only on the basis of the greed of everyone, the efficient working of the capitalist economy is, in fact, dependent on powerful systems of values and norms. Indeed, to see capitalism as nothing other than a system based on a conglomeration of greedy behavior is to underestimate vastly the ethics of capitalism, which has richly contributed to its redoubtable achievements. (1999a, p. 262)

Sen is far from attributing any hunger for profit or free market entrepreneurship as capitalism's ethic. Indeed, his wide reading of Adam Smith leads him to reject the significance traditionally placed on Smith's description of 'the butcher, the brewer, or the baker' being motivated through 'regard to their own interest'. Sen complains:

Unfortunately, in some schools of economics the reading of Smith does not seem to go much beyond those few lines, even though that discussion by Smith is addressed only to one very specific issue, namely exchange (rather than distribution or production), and in particular, the motivation underlying exchange (rather than what makes normal exchanges sustainable, such as trust and confidence in each other). (2010, p. 55)

He makes reference to virtue when noting how ' $[\mathrm{t}]$ here are plenty of examples of the problems faced in precapitalist economies because of the underdevelopment of capitalist virtues' (1999a, p. 263), and singles out trust and honesty:

In social interactions, individuals deal with one another on the basis of some presumption of what they are being offered and what they can expect to get. In this sense, the society operates on some basic presumption of trust. Transparency guarantees deal with the need for openness that people can expect: the freedom to deal with one another under guarantees of disclos ure and lucidity. (p. 39) 
It is not at first obvious how Sen can come to acknowledge the basic cooperation underpinning economic activity whilst simultaneously respecting neoclassical theory. A case in point is how Sen agrees with Arrow's impossibility theorem - that individual preferences, when expressed by means of limited categories, cannot be aggregated in such a way as to be a true and stable reflection of the original preference orderings of those individuals. ${ }^{6}$ Sen navigates discussion of the theorem with awareness of where the theorem applies and where it does not, allowing him critical distance from the homo economicus assumptions at the heart of Arrow's framework. Sen explains that Arrow's impossibility theorem 'does not at all rule out decision mechanisms that use more-or differentinformational bases than voting rules do' and pushes the point further by writing how the inconsistency arrived at through applying a majoritarian voting system to a social problem 'may well be seen not so much as a problem, but as a welcome relief from the unswerving consistency of brutal and informationally obtuse procedures' (1999a, pp. 251-2; see also Sen, 1999b).

Understanding in detail the actual remit of the impossibility theorem means Sen is able to suggest that 'through informational broadening, it is possible to have coherent and consistent criteria for social and economic assessment' (1999a, p. 253). ${ }^{7}$ What this might mean for social science methodology is outlined in a 1977 article which heavily criticises existing behavioural economic theory. Sen notes the futility of scaling all preferences according to utility and affirms:

A person thus described may be "rational" in the limited sense of revealing no inconsistencies in his choice behavior, but if he has no use for these distinctions between quite different concepts, he must be a bit of a fool. The purely economic man is indeed close to being a social moron. Economic theory has been much preoccupied with this rational fool decked in the glory of his one all-purpose preference ordering. To make room for the different concepts related to his behavior we need a more elaborate structure. (p. 336)

In his discussion, Sen distinguishes between the human motivations of sympathyand commitment, arguing the latter to lie outside the realm of material incentives. If sympathy is where 'the concern for others directly affects one's own welfare', commitment is where 'it does not make you feel personally worse off, but you think it is wrong and you are ready to do something to stop it' (p. 326). A distinction along these lines has been empirically observed in studies that consider the importance of nonmaterial, moral motivations for explaining why people trust (Uslaner, 2002). Sen explains the difference with a story of two boys who come across a small apple and a big apple:

Boy $A$ tells boy $B$, "You choose." $B$ immediately picks the larger apple. $A$ is upset and permits himself the remark that this was grossly unfair. "Why?" asks $B$. "Which one would you have chosen, if you were to choose rather than me?" "The smaller one, of course," $A$ replies. $B$ is now triumphant: "Then what are you complaining about? That's the one you've got!" $B$ certainly wins this round of the argument, but in fact $A$ would have lost nothing from $B$ s choice had his own hypothetical choice of the smaller apple been based on sympathy as opposed to commitment. $A$ 's anger indicates that this was probably not the case. (1977, pp. 328-9)

The account provides a robust example of when moral commitments cannot be integrated into utility based frameworks, inviting other ethical frameworks for interpreting economic decision-making. 
It is by reason of his appreciation of the incommensurability of human goods - between moral and material reasoning - that Sen models human interests in terms of ' rankings of preference rankings to express our moral judgments' (1977, p. 337). This equally holds for Sen's argument on the impossibility of a "Pareto liberal", which demonstrates that, when attempting Pareto improvements (making some people better off without others being made worse off), simultaneously respecting everyone's preference orderings in a liberal manner frequently arouses decision-making incompatibilities (1970, p. 157). ${ }^{8}$ We so often have preferences about other people's conduct that it is a fallacy to think Pareto improvements can be consistently made without some people feeling their interests are threatened (e.g. a neighbour receives a windfall of cash to paint her house pink, pleasing her but annoying her neighbours). A liberal position must therefore be preferred by everyone for its own sake before it can work towards a utilitarian efficiency solution of Pareto improvements. As such, 'arguments turn on a ranking of preference orderings' (Sen, 1974, p. 65; see also Sen, 1971, chapter 6), and there becomes nothing a-normative about saying the other should do as he pleases as it requires the other also believe the principle. As Sen remarks elsewhere: 'The relevance of non-utility information to moral judgments is the central issue involved in disputing welfarism. Libertarian considerations point towards a particular class of non-utility information' (1979, p. 212).

Acknowledging non-utility information may occur, however, without any particular affinity to the virtue ethics tradition, so what links Sen's considerations of rankings of preference rankings to Aristotelian considerations of virtues as good habits? Over the course of a long and profound career, Sen draws from many sources and traditions, making it impossible to identify one in particular as a superior influence. The claim here is not, therefore, that his approach can be explained away by reference to Aristotle. Rather, it is the more limited observation that some of the economic conundrums Sen has grappled with have been faced with supporting assistance from an approach complementary to the virtue ethics school. The point of connection between the two is not prescriptive ethics, however, but methodological openness to heterogeneity of decision procedures among actors. This, in turn, gives room for practical reason as an operative principle for the diversity of human aims. ${ }^{9}$ It is a position shared between Sen and the virtue ethics tradition, suggesting to new researchers how much can be gained by drawing from both perspectives in equal measure. Take, for example, the following comment from virtue ethicist Rosalind Hursthouse:

from the point of view of those who think a normative ethics should produce a decision procedure, virtue ethics does reject codifiability and thereby provides inadequate action guidance. […]

One form the criticism persists in is the claim that virtue ethics lamentably fails to come up with a priority ranking of the virtues. Just appealing to them is not enough; they, and the corresponding v-rules, must be supplemented by rules or principles to the effect that, say, honesty outranks kindness; without this, its action guidance is inadequate. (2001, p. 56)

Mirroring Sen's reluctance to discuss any one theory as rationally or efficiently ordering preferences for all, Hursthouse bristles at the demand that virtue ethics provide a falsifiable prescription of correct action. Rather, Hursthouse believes this ultimately unacceptable demand blinds the theorist from 
appreciating human complexity and the role of practical wisdom. In meeting this criticism of inadequate action guidance, Hursthouse affirms:

The very idea that even the ideally morally wise could rank the virtues, or the deontologists' rules, or grasp an algorithm for their weighting, just seems to me to be giving up on the insights gained from considering what can actually be said about the resolutions of real-life hard cases. When we look at their resolutions, we see that we bring a variety of considerations to bear on different cases; sometimes one consideration is centrally, even overridingly, important; on other occasions we just put it to one side, on others we do not worry about how important it is because it is combined with others in such a way as to settle the issue [...]. Any codification ranking the virtues, like any codification ranking the rules, is bound to come up against cases where we will want to change the rankings. (2001, p. 57)

Deepening understanding of individual and social preferences through methodological openness to possible heterogeneity of decision procedures links both with Sen's general commitment to "real-life" economic dilemmas ${ }^{10}$ and his philosophical grounding in Aristotle. In Development as Freedom, Sen refers in six passages to Aristotle, of which four also make reference to complementary works of Martha Nussbaum (Sen, 1999a, pp. 14-5, 24-5, 73, 74-5, 249, 289).11 The value of this bears fruit in allowing Sen to explore goods from a grassroots perspective. As he remarks, 'the Aristotelian account of the human good (as Martha Nussbaum discusses) was explicitly linked to the necessity to "first ascertain the function of man" and then proceeded to explore "life in the sense of activity" as the basic block of normative analysis' (1999a, p. 73). This gives Sen deep-seated appreciation of persons' diverse formulation of ends. It also provides him with a link to questions of normativity which dodges accusations of elitist prescription of any particular ethical theory (thus meeting Arrow's concern). Supporting this process is Sen's more holistic use of Smith, whereby valuation is made not just of the invisible hand of indirect consequences but also Smith's appreciation of the direct force of actual social interactions in The Theory of Moral Sentiments. As Smith remarks there, 'whatever may be the cause of sympathy, or however it may be excited, nothing pleases us more than to observe in other men a fellow-feeling with all the emotions of our own breast; nor are we ever so much shocked as by the appearance of the contrary' (1761, p. 10).

Taken together, these philosophical angles generate in Sen strong acknowledgement of the communicative and social aspects of economic exchange. The parallels of this with a virtue ethics approach are only too clear when comparing Sen's understanding of the market as a whole to that provided by Bruni and Sugden:

markets facilitate mutually beneficial voluntary transactions. Such transactions can be seen as valuable because individuals want to make them, because they satisfy individuals' preferences, because they create wealth, and because the opportunity to make them is a form of freedom. We therefore propose to treat mutual benefit as the telos of the market. (2013, p. 153)

The key move is in linking market purpose to human purpose, in a way that respects direct human intention and reasoning as a fundamental addition to the market's indirect logic. Sen notes, for example, that 'there is some social loss involved in denying people the right to interact economically 
with each other' (1999a, p. 26) and draws a kind of parity between being able to engage in economic activity and being able to communicate:

To be generically against markets would be almost as odd as being generically against conversations between people (even though some conversations are clearly foul and cause problems for others-or even for the conversationalists themselves). The freedom to exchange words, or goods, or gifts does not need defensive justification in terms of their favourable but distant effects; they are part of the way human beings in society live and interact with each other (unless stopped by regulation or fiat). The contribution of the market mechanism to economic growth is, of course, important, but this comes only after the direct significance of the freedom to interchange—words, goods, gifts—has been acknowledged. (p. 6)

Sen goes so far as to take forward these connections between the direct and indirect significance of the market to show how ideas of justice are not institutionally or arbitrarily imposed but arise in persons 'who worry about their own interests but are also able to think about family members, neighbours, fellow citizens and about other people in the world' (p. 262).12 The depth of this position is made clear in Sen's conception of the agent, who, in line with an Aristotelian approach, aims at selfperceived goods:

The expression "agent" is sometimes employed in the literature of economics and game theory to denote a person who is acting on someone else's behalf (perhaps being led on by a "principal"), and whose achievements are to be assessed in the light of someone else's (the principal's) goals. I am using the term "agent" not in this sense, but in its older - and "grander"- - sense as someone who acts and brings about change, and whose achievements can be judged in terms of her own values and objectives, whether or not we assess them in terms of some external criteria as well. (1999a, pp. 18-9)

Arrow identified the limits to strict institutional analysis but was unable to encourage further debate on the interpersonal dynamics of institutional creation because he lacked a communicative, intersubjective or heterogeneous understanding of agents. In trying to answer a similar question of the limits of prescribing institutions for ensuring development, Sen provides this description of the agent through Aristotelian attention to the person's telic capabilities. Purposeful market interaction and self-defined goals are central, and so value-based action remains rational and integral to understanding the economy even from an economist's perspective.

\section{Elinor Ostrom}

As part of an extensive inquiry into human cooperation, Ostrom analyses institutions through the rules, norms and practices persons use to navigate social questions. As with the two other authors discussed in this argument, Ostrom focuses on human cooperation and yet goes further than Arrow and Sen in claiming that 'the theory of collective action is the central subject of political science' (1998, p. 1). In a later piece she revisits this claim and comments: 'I made this bold assertion becau se collective action problems pervade the study of comparative politics at all levels from local neighborhoods 
through international regimes' (2009, p. 186). Because in every society the norms of reciprocity used to solve such dilemmas share 'common ingredients' (2003, p. 42), Ostrom develops a universal framework for interpreting institutional diversity, systematising Arrow's position of the fallibility of strictly structural explanations. ' [I $]$ nstitutions are the prescriptions that humans use to organize all forms of repetitive and structured interactions including those within families, neighborhoods, markets, firms, sports, leagues, churches, private associations, and governments at all scales' (Ostrom, 2005, p. 3). Marking out the challenge to the social sciences, Ostrom (2005, p. 68) emphasises the 'substantial challenge in animating institutional analyses' that has come to the fore because of the nonlinear relationship observed between formal institutions and social outcomes. In order for the social sciences to progress, there is a need to 'develop tools of analysis that reconnect the normative side of individual orientations with the calculation of individual benefits' (p. 111 ). Responding to this need, she examines settings 'in which individuals choose actions in an interdependent situation', bringing attention to bear on social dilemmas as the most relevant citizen-on-citizen encounters (2009, p. 186).

Interest in the formation of interpersonal rules and norms plays out alongside awareness of Arrow's 1974 piece, which Ostrom and Walker note as stressing 'the ubiquity of trust in almost every economic transaction' (2003, p. 6). In a later publication, Ostrom develops the point further by making explicit reference to social capital, which she views as exhibiting three types 'particularly important in the study of collective action: (1) trustworthiness, (2) networks, and (3) formal and informal rules or institutions' (Ostrom \& Ahn, 2009, p. 20). This connects interpersonal dynamics with the formation of social capital, not based on first-generation economic theories of atomistic, selfish individuals but on a second-generation that takes 'heterogeneous preferences seriously' (pp. 19-22). Ostrom accepts 'genuine trustworthiness, defined in terms of preferences that are consistent with conditional cooperation, as independent and non-reducible reasons why some communities achieve collective action while others fail'. Through this, it becomes easy to see how 'trust is the core link between social capital and collective action' (p. 22).

In this way, Ostrom questions structural factors as all-encompassing determinants of social outcomes, pointing out how ' $[\mathrm{t}]$ here is no way that one can analyze the entire "spaghetti plate" of variables that have been identified and their interactions in a single empirical analysis' (2009, p. 203).13 It is not just that Ostrom sees difficultly; she insists on an almost constant disjuncture between structural causes and social outcomes, complaining that the model of the person being used in the social sciences must be at fault:

None of these structural variables [...] should really make any difference in the probability of successful collective action if we continue to treat the model of rationality that has proved successful in explaining behavior and outcomes in competitive market settings as a universal theory of human behavior. (2009, p. 187; see also Ostrom, 2005, pp. 102-3, 253-4)

The answer is to turn to 'a theory of boundedly rational, norm-based human behavior' (Ostrom, 2009, p. 187). What are we to make of such a response? 
The first point to clarify is that, as with Bruni and Sugden's contribution (2008, p. 41), Ostrom's position does not return social scientists to the binary debate over human nature as either self-seeking or other-seeking. She explicitly rejects altruism as holding any special explanatory power over its rival, selfishness, and avoids saying the experimental social science literature has argued the case successfully one way or the other:

\begin{abstract}
Although many researchers have focused on the unexpectedly high rates of cooperation [in experimental games], it is important to note that in sparse institutional settings, cooperation levels never reach the optimum. Thus, though the prediction of zero levels of cooperation can be rejected, cooperation at a suboptimal level is consistently observed in sparse settings. (2003, p. 28; see also p. 39)
\end{abstract}

It is on the basis of behavioural observation, therefore, that Ostrom rejects simply changing 'from an assumption of universal selfish behavior to an assumption of universal altruism' (2005, p. 110).

Instead, she moves to a boundedly rational and norm-based view of the person, more complicated than either self- or other-regarding preference computations. In advance of this, Ostrom draws on Sen to push against too thin an understanding of rationality:

[W]hat has come to be called rational-choice theory in the social sciences is instead one model in a family of models useful when conducting formal analyses of human decisions in highly structured physical and institutional settings. As Amartya Sen points out in his presidential address to the American Economic Association, "There are many different conceptions of rational behavior of the individual". The model of complete rationality most frequently used in rational-choice explanations is one model of these different conceptions. (Ostrom, 2003, p. 25) ${ }^{14}$

Maintaining the term "rational", Ostrom concentrates on its bounded nature, harking back to Herbert A. Simon's 'principle of bounded rationality' (1957, p. 199). Ostrom's use of the concept describes how individuals tend to use heuristics — rules of thumb - that they have learned over time regarding responses that have, in the past, brought them good outcomes' (2003, p. 40; see also Ostrom, 2005, p. 118). This, in turn, supports a process of common knowledge accumulation:

boundedly rational individuals would expect other boundedly rational individuals to follow a diversity of heuristics, norms, and strategies rather than expecting to find others adopting a single strategy - except in those repeated situations in which institutional selection processes sort out those who do not search out optimal strategies. One does not have to assume that others are "irrational" in order for it to be rational to use reciprocity. (Ostrom, 2003, p. 46)

Ostrom sometimes goes so far as to describe possible explanations as identifying 'a form of "mind reading" whereby decision makers contemplate the possible behavior of those with whom they may interact' (Ostrom \& Walker, 2003, p. 1 1),15 and participate in 'shared mental models' (Ostrom, 2005, p. 108). This gives room for negotiating how norms and rules of conduct are able to emerge from repeated application of heuristic guides. Collective action dilemmas become disagreements over rules and which moral principle should be applied, and their solution lies in shared normative frameworks and trust (Ostrom, 2000). 
Such innovation, however, leads to the question of what exactly is bounded about bounded rationality. Ostrom describes her position as committed to individuals being 'rational in a broad sense', and counts this as wider than the stance of rational choice theory because 'complete rationality is the limiting case of bounded or incomplete rationality' (2003, p. 39). As with Sen's stance, we can note here a flip in the use of conceptions of rationality. Social science in the $19^{\text {th }}$ and $20^{\text {th }}$ centuries took the interest-maximising individual as a coherent reference point for joining macro social outcomes to individual behaviour. The $21^{\text {st }}$ century instead hosts a countervailing trend: identification of an interest-maximising assumption becomes a coherent reference point for a theory's dismissal. A more holistic understanding of the person is seen as a knowledge gain over the rational choice model, and achieving this lies in researching how norms, morals and rules are formed at the level of agents. If the theoretical contribution of a study includes no stable addition to the model of homo economicus, there is no knowledge gain.

Ostrom makes heavy use of laboratory experiments of cooperative dilemmas in making her assessments. It is worth noting that, because of a preference for analytical clarity, experimental economics tends to shy away from facing participants with multiple social dilemmas simultaneously. Doing so would, however, more readily lead researchers to interpret the person as character-based; that is, discussing reputation, dispositions and preferences in terms of socially accrued characters that have communal meaning and make sense of varied challenges. ${ }^{16}$ Compared against such understandings of character, Ostrom's claim that a 'broader theory of human behavior views humans as fallible cognizers' perhaps comes across as limited (2003, p. 25). The root cause of this is that Ostrom provides little basis for the initial formation of those hermeneutical guides which provide the person with normative prescriptions for social dilemmas. Her presidential address opened with Hobbes finding the question of how humans come to cooperate 'impossible' (2003, p. 19), and yet she returns again to the $17^{\text {th }}$ century English philosopher in a later publication, describing him as having identified a common denominator in agents' behaviour in 'strictly physical strength' (2005, p. 60). Her hesitancy with Hobbes reflects her fragile and yet thrilling problematisation of the individual, giving space in turn for greater appreciation of the role of practical reason in human decision-making. The model of 'boundedly rational, norm-based human behavior' is still in need of much more analytical detail, but it nevertheless meets with virtue ethics' approach of emphasising the communicative capacities of human motivation.

\section{Conclusion}

These three authors leave trails suggestive of how microeconomic and behavioural theory is being developed in a way increasingly compatible in its methodology with a virtue ethics approach. Arrow explains the limits of organisations, and the need for understanding how institutions are undergirded by social virtues. Sen expands the view of the person, taking seriously heterogeneity of preferences 
and agent conceptions of the good. Ostrom, finally, analyses the limitations of formal institutions with the aid of diversity in human behaviour and brings attention to bear on the social norms that facilitate coordination of action in the midst of heterogeneous group membership. These three contributors attend to the question of why humans cooperate and, in their responses, each help to develop methodological strategies in proximity to virtue ethics' attention to societal norms and human capacities to communicate.

Just as Bruni and Sugden engineer a defence of economics on virtue ethics grounds, so is there a need to evaluate strains within economics that invite con tributions from virtue ethics. The article has sourced interrelated research in micro and behavioural economic theory that asks deeper questions of human beings' habits and normative communication. This does not set-up virtue ethics as the only way forward for further research in these areas, but does demonstrate a key zone of mutual collaboration and critical engagement.

It is impossible to explain trust, social capital or human cooperation from an individualistic perspective, necessary as it is to engage in socially-accrued interpretations of reputation, good conduct and trustworthiness. An Aristotelian understanding of communicable virtues bridges the gap between micro dynamics of interpersonal behaviour and the formation of social norms and habits of cooperation of use to the economy as a whole. Not only can economics best defend itself against accusations from virtue ethicists by articulating the market as a zone for virtuous exchange, much of the perspective of the virtue ethics school is already finding space in economic theory. This, I believe, is a good thing. For just as virtue ethics bases itself on the communicability of ends, so too can its approach flourish in a communicability of disciplines.

\section{References}

Annas, J. (201 1). Intelligent Virtue. Oxford: Oxford University Press.

Arrow, K. J. (1969). The Organization of Economic Activity: Issues Pertinent to the Choice of Market versus Non-market Allocation. Joint Economic Committee of Congress.

Arrow, K. J. (1970). Political and Economic Evaluation of Social Effects and Externalities. Ch 1 of J. Margolis (Ed.), The Analysis of Public Output. New York: National Bureau of Economic Research.

Arrow, K. J. (1972). Gifts and Exchanges. Philosophy \& Public Affairs, 1(4), 343-362.

Arrow, K. J. (1974). The Limits of Organization. London: W. W. Norton.

Arrow, K. J. (2000). Observations on social capital. Ch 1 of P. Dasgupta, \& I. Serageldin (Eds.), Social Capital: A Multifaceted Perspective. Washington, DC: The World Bank.

Arrow, K. J. (2012). Social Choice and Individual Values. London: Yale University Press.

Banfield, E. C. (1958). The Moral Basis of a Backward Society. USA: The Free Press (with L. F. Banfield).

Bohm, P. (2008). External economies. In S. N. Durlauf, \& L. E. Blume (Eds.), The New Palgrave Dictionary of Economics (2nd ed.), 6. New York: Palgrave MacMillan.

Bruni, L., \& Sugden, R. (2008). Fraternity: Why the Market Need Not be a Morally Free Zone. Economics and Philosophy, 24(1), 35-64. 
Bruni, L., \& Sugden, R. (2013). Reclaiming Virtue Ethics for Economics. Journal of Economic Perspectives, $27(4), 141-164$.

Chamberlain, C. (1984). The Meaning of Prohairesis in Aristotle's Ethics. Transactions of the American Philological Association, 114, 147-157.

Comim, F. (2008). Social Capital and the Capability Approach. Ch 22 of D. Castiglione, J. W. van Deth, \& G. Wolleb (Eds.), The Handbook of Social Capital. Oxford: Oxford University Press.

Crespo, R. F. (2013). Theoretical and Practical Reason in Economics: Capacities and Capabilities. Dordrecht: Springer.

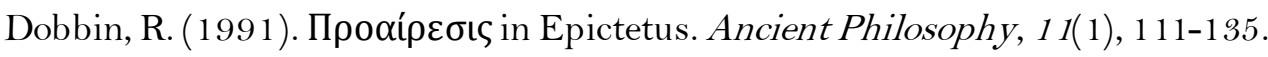

Finnis, J. (1990). Allocating Risks and Suffering: Some Hidden Traps. Cleveland State Law Review, $38,193-207$.

Gambetta, D. (1988). Can We Trust Trust? Ch 13 of D. Gambetta (Ed.), Trust: Makingand Breaking Cooperative Relations. Oxford: Blackwell.

Hume, D. (1978 [1739-40]). A Treatise of Human Nature(2nd ed.). Oxford: Oxford University Press.

Hursthouse, R. (2001). On Virtue Ethics. Oxford: Oxford University Press.

Knack, S. (2002). Social Capital and the Quality of Government: Evidence from the States. American Journal of Political Science, 46(4), 772-785.

MacIntyre, A. (1985). After Virtue: a study in moral theory (2nd ed.). London: Duckworth.

McCabe, K. (2003). A Cognitive Theory of Reciprocal Change. Ch 6 of E. Ostrom, \& J. Walker (Eds.), Trust and Reciprocity: Interdisciplinary Lessons from Experimental Research. New York: Russell Sage Foundation.

Nussbaum, M. (1993). Non-Relative Virtues: An Aristotelian Approach. In M. Nussbaum, \& A. Sen (Eds.), The Quality of Life (pp. 242-269). New York: The United Nations University.

Ostrom, E., \& Ahn, T. K. (2009). The meaning of social capital and its link to collective action. Ch 2 of G. T. Svendsen, \& G. L. H. Svendsen (Eds.), Handbook of Social Capital: The Troika of Sociology, Political Science and Economics. Edward Elgar: Cheltenham.

Ostrom, E., \& Walker, J. (2003). Introduction. Ch 1 of E. Ostrom, \& J. Walker (Eds.), Trust and Reciprocity: Interdisciplinary Lessons from Experimental Research. New York: Russell Sage Foundation.

Ostrom, E. (1998). A Behavioral Approach to the Rational Choice Theory of Collective Action: Presidential Address, American Political Science Association, 1997. American Political Science Review, 92(1), 1-22.

Ostrom, E. (2000). Social capital: a fad or a fundamental concept? Ch 9 of P. Dasgupta, \& I. Serageldin (Eds.), Social Capital: A Multifaceted Perspective. Washington, DC: The World Bank.

Ostrom, E. (2003). Toward a Behavioral Theory Linking Trust, Reciprocity, and Reputation. Ch 2 of E. Ostrom, \& J. Walker (Eds.), Trust and Reciprocity: Interdisciplinary Lessons from Experimental Research. New York: Russell Sage Foundation.

Ostrom, E. (2005). Understanding Institutional Diversity. Princeton: Princeton University Press.

Ostrom, E. (2009). Collective Action Theory. Ch 8 of C. Boix, \& S. C. Stokes (Eds.), The Oxford Handbook of Comparative Politics. Oxford: Oxford University Press.

Putnam, R. D., \& Feldstein, L. M. (2003). Better Together: Restoring the American Community. New York: Simon \& Schuster (with D. Cohen).

Putnam, R. D. (1993). Making Democracy Work. Princeton: Princeton University Press (with R. Leonardi, \& R. Nanetti).

Putnam, R. D. (2000). Bowling Alone: The Collapse and Revival of American Community. New York: Simon \& Schuster.

Robison, L. J., Allan Schmid, A., \& Siles, M. E. (2002). Is Social Capital Really Capital? Review of Social Economy, $60(1), 1-21$. 
Sandel, M. J. (2012). What Money Can't Buy: The Moral Limits of Markets. New York: Farrar, Straus and Giroux.

Sen, A. (1970). The Impossibility of a Paretian Liberal. Journal of Political Economy, 78(1), 152-157.

Sen, A. (1971). Collective Choice and Social Welfare. London: Oliver \& Boyd.

Sen, A. (1974). Choice, Orderings and Morality. Ch 2 of S. Körner (Ed.), Practical Reason. Oxford: Basil Blackwell.

Sen, A. (1977). Rational Fools: A Critique of the Behavioral Foundations of Economic Theory. Philosophy \& Public Affairs, 6(4), 3 17-344.

Sen, A. (1979). Equality of What? The Tanner Lecture on Human Values. Stanford University.

Sen, A. (1995). Rationality and Social Choice. American Economic Review, 85(1), 1-24.

Sen, A. (1999a). Development as Freedom. Oxford: Oxford University Press.

Sen, A. (1999b). The Possibility of Social Choice. American Economic Review, 89(3), 349-378.

Sen, A. (2009). The Idea of Justice. London: Penguin.

Sen, A. (2010). Adam Smith and the contemporary world. Erasmus Journal for Philosophy and Economics, 3(1), 50-67.

Simon, H. A. (1957). Models of Man: Social and Rational. New York: John Wiley.

Smith, A. (1761). The Theory of Moral Sentiments (2nd ed.). London: Printed for A. Millar, A. Kincaid, \& J. Bell.

Titmuss, R. M. (1970). The Gift Relationship: From Human Blood to Social Policy. Middlesex: George Allen \& Unwin.

Uslaner, E. M. (2002). The Moral Foundations of Trust. Cambridge: Cambridge University Press.

Wells, T. R. (2014). Theoretical and practical reason in economics: capacities and capabilities. Journal of Economic Methodology, 21(2), 202-207.

Woolcock, M. (1998). Social capital and economic development: Toward a theoretical synthesis and policy framework. Theory and Society, $27(2), 151-208$.

\section{Notes}

\footnotetext{
${ }^{1}$ However, it would be unfair to criticise Titmuss on this basis as he does distinguish between Gemeinschaft (community) and Gesellschaft (society) relationships and associates altruism more closely with the former and not the latter's price-conducive mechanism (Titmuss, 1970, pp. 238-9).

2 This logic is also noted by Amartya Sen, who writes: 'The importance of unintended consequences has been emphasized in different ways by Adam Smith, Carl Menger and Friedrich Hayek, among others. If most of the important things that happen are not intended (and not brought about through purposive action), then reasoned attempts at pursuing what we want might appear to be rather pointless.' (1999a, p. 250).

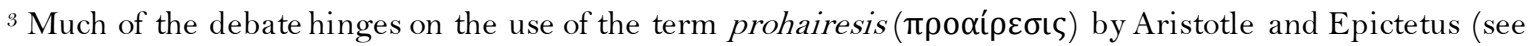
Chamberlain, 1984; Dobbin, 1991).

${ }^{4}$ Robison et al further argue against the required 'alienability' of capital (pp. 16-7; see also Woolcock, 1998).

${ }^{5}$ Greek for ends, purposes or final aims.

${ }^{6}$ Assuming individuals have at least three options to choose from and there is no dictator able to change others' preference orderings (see Arrow, 2012).

${ }^{7}$ Earlier, Sen toys with the idea of seeing individuals as sharing preference sets but rejects this as a deeply problematic assumption (1999a, pp. 68-9).

${ }_{8}$ As Sen explains, 'a principle reflecting liberal values even in a very mild form cannot possibly be combined with the weak Pareto principle, given an unrestricted domain' (1970,p. 157).

9 As Crespo explains, 'The kind of decisions that the agent has to make thus entails a broader use of reason than merely instrumental reason. Sen asserts that "rationality cannot be just an instrumental requirement for the pursuit of some given-unscrutinized - set of objectives and values". It should also scrutinize these objectives and values. It includes the use of reason to understand and assess goals and values, that is, practical reason' (Crespo, 2013, p. 46). For criticism of the connections Crespo makes, see Wells (2014).

10 See, for example, Sen's citing of a formative encounter with a wounded man in Dhaka, Bangladesh, and his criticism of impartial policymaking in cases of famine (Sen, 1999a, pp. 8, 209).
} 
${ }^{11}$ As an example of Nussbaum's approach to Aristotle, see Nussbaum (1993). For an argument connecting the capabilities approach of Sen and Nussbaum to the concept of social capital, see Comim (2008).

12 See also the preferred concern for resolving injustices rather than developing theoretical abstractions of justice in Sen (2009).

13 This is perhaps implicit reference to Putnam's comment: 'The causal arrows among civic involvement, reciprocity, honesty, and social trust are as tangled as well-tossed spaghetti' (2000, p. 137).

14. The within-text quotation appears in Sen $(1995$, p. 2). Ostrom comments in her footnote: 'At the same time that complete rationality makes heroic assumptions about information-processing capabilities, it also presents a thin perception of the capacity of humans for moral reflection and commitment' (2003, p. 64, fn. 3). Reference at this point is made to Sen (1977; see also Ostrom, 2005, pp. 111-2).

${ }^{15}$ Here the authors are describing the findings of McCabe (2003).

16 Through a communal sense of character, for example, we are able to imagine what Jack would be likely to do if we found him at the top of an enormous beanstalk and near a giant's house full of riches. Jack may have acted differently to how homo economicus would (especially going back a third time after already getting a hen that lays golden eggs) but this does not mean Jack's actions qua Jack lack coherence. Further, this is not to say Jack's actions are unintelligible through a process of rational choice induction, only that an awareness of Jack's character trait of naïve optimism gives a more consistent explanation as to why he both sold his only cow for magic beans and dared to enter a giant's house on three separate occasions. 